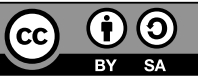

DOI: https://doi.org/10.4312/keria.20.2.89-114

\title{
Lara Unuk
}

\section{Svobodni duh Jorgosa Teotokasa in koncept generacije tridesetih}

\section{UVOD}

V obdobju med obema vojnama se je $\mathrm{v}$ grškem kulturnem življenju pojavila zahteva po literarno-kulturnem preporodu, iz katere je vzniknila literarna generacija tridesetih let. Njene predstavnike družijo predvsem skupna miselnost in prizadevanja za razvijanje zvrsti eseja in romana, v poeziji prostega verza, kar se tiče literarnega sloga, pa se navdihujejo pri različnih sočasnih evropskih smereh. Posledično bi težko govorili o literarni šoli v strogem pomenu. Kljub omenjenemu pridržku so se prve opredelitve generacije tridesetih pojavile že skoraj sočasno z njenimi najzgodnejšimi deli, pravzaprav so ta pojem sproti in načrtno razvijali njeni pripadniki sami in ga vpeljali kot literarnozgodovinski termin morda deset ali dvajset let po njeni pojavitvi. Sploh prozaisti generacije tridesetih so bili pogosto tudi njeni teoretiki in kritiki.

Čeprav je v sodobni grški literarni zgodovini generacija tridesetih pogosta tema obravnave, saj je grški književnosti dala mnoga klasična dela in dva nobelovca, Seferisa in Elitisa, pa ni bil nikdar dosežen popoln konsenz glede njene definicije. Zdi se, da preučevalci generacije tridesetih v tem smislu niso naredili koraka naprej in zgolj ponavljajo trditve in samodefinicije avtorjev tistega časa, na katere pa je odločilno vplivalo, da so ustvarjali v obdobju burnih političnih sprememb. Prav v tem je po moji presoji iskati razlog, da se še danes govori predvsem o $»$ ideologiji generacije tridesetih, njene znotrajliterarne poteze pa so nekako sekundarne. Pogosto jo obravnavajo bolj v kontekstu političnih ideologij (socializma, fašizma, liberalizma) kot v kontekstu evropske avantgarde in literarnih šol, izraz »avantgarda " pa njeni preučevalci uporabljajo, kadar govorijo o vpeljavi modernističnih tehnik. Ena izmed značilnosti, ki jih pripisujejo generaciji tridesetih, je prizadevanje, da bi razvili »novo grškost«, težnja, ki jo moramo povezati z nedavno osvoboditvijo izpod Otomanskega imperija. 
V prispevku nameravam na kratko prikazati, na kakšen način so avtorji, ki so pisali v enem najpomembnejših obdobij grške literature, ustvarjali skupno identiteto (ali se ji odrekali) in kako so se samodefinirali kot "generacija", ne da bi se kadar koli povezali v formalno literarno šolo, pri tem pa so vzpostavili še danes nepreseženo in na videz nepresegljivo normo. Posebej bom izpostavila prispevek enega izmed njenih poglavitnih idejnih in literarnih predstavnikov, Jorgosa Teotokasa, saj je bil ta ključna osebnost tako pri izoblikovanju novega pojmovanja književnosti kot pri nastanku koncepta generacije tridesetih, vključno z natančnim branjem njegovega prvega eseja, Svobodnega duha, ki danes velja za ustanovni tekst te šole ali bolje rečeno gibanja.

Vzpon generacije tridesetih je organsko povezan s spremembami v evropski in grški miselnosti, zato jo v prispevku predstavljam predvsem v tej luči in vključujem tudi predstavitev literarnega prizorišča tistega časa ter poglavitnih predhodnikov. Pri tem se opiram na temeljna dela o generaciji tridesetih: Generacija tridesetih: Ideologija in oblika Maria Vittija, Mit generacije tridesetih: Modernost, grškost in teorija kulture Dimitrisa Tziovasa ter Uvod v Antologijo književnosti med obema vojnama Panajotisa Mulasa.

\section{GRŠKA KNJIŽEVNOST V DVAJSETIH LETIH 20. STOLETJA}

Politično in družbeno vzdušje je bilo v Grčiji dvajsetih let turobno, saj je bil spomin na "maloazijsko katastrofo « ${ }^{1}$ iz leta 1922 še svež. Vojne grozote, propad »velike ideje o državni širitvi ${ }^{2}$ in ekonomsko-družbena kriza zaradi množičnega prihoda izgnancev $\mathrm{z}$ obal Male Azije so našli odsev v književnosti, $v$ kateri je posledično prevladovalo občutenje melanholije in brezizhodnosti. Za resno književnost sicer $\mathrm{v}$ tistem obdobju ni bilo veliko zanimanja, največ uspeha so želi pogrošni romani in žanrska literatura. Literarna proza je izhajala večinoma po revijah in dnevnih časopisih, manj pa v knjižni obliki.

V pesništvu je bil najizrazitejši glas Kostasa Kariotakisa, ${ }^{3}$ ki je upesnjeval jalovost obstoja, preminevanje in nesmiselnost vsega človeškega početja. Njegova

1 Izraz »maloazijska katastrofa« se v grškem zgodovinopisju uporablja za grški poraz v ozemeljski vojni s Turčijo v okolici Smirne, ki se je iztekel v pokole in delovna taborišča, ter za prisilno izmenjavo ljudstev med Grčijo in Turčijo, ki mu je sledila 1.1923 in namen katere je bila vzpostavitev etnične enotnosti znotraj obeh držav. V tem obdobju so Grčijo preplavili begunci s turškega ozemlja.

2 Vse od srede 19. stoletja so si grške vlade prizadevale za zavzetje vseh tistih pokrajin Otomanskega imperija, kjer se je nahajala številčna grška, tj. ortodoksna, populacija, skupaj z južnim Balkanom in Malo Azijo. Bistvo ideje je bilo, da naj bi Grčija zaobjemala bolj ali manj vsa področja, ki so ji pripadala kdaj v antiki ali Bizancu.

3 Kostas Kariotakis (1896-1928), pesnik in prozaist, je bil eden glavnih predstavnikov grškega pesniškega modernizma. Izdal je tri pesniške zbirke: Bolečina ljudi in stvari (1919), Nepent (1921) ter Elegije in satire (1927). Leta 1928 se je ustrelil v Prevezi, kjer je deloval kot uradnik pri dodeljevanju ozemlja pribežnikom iz Male Azije. Vplival je na znana pesnika Seferisa in Ritsosa, njegove pesmi pa so prevedene $\mathrm{v}$ več kot trideset jezikov. 
melanholična poezija in samomor sta navdihnila lirično pesniško modo, imenovano kariotakizem. Postal je vzornik tako sodobnim kot mlajšim pesnikom, ki so pisali pesmi, polne cinizma, eksistencialnega obupa in razočaranja.

Prevladujoča usmeritev v prozi se ni spremenila približno od leta 1880: značilna je tako imenovana itografija ( $\eta \theta 0 \gamma \rho \alpha \varphi i \alpha)$, kar lahko prevedemo kot "popisovanje šeg«. Ta literarna šola se je oblikovala pod vplivom nacionalistične, narodnobuditeljske ideologije in naglega razcveta etnologije na grških tleh, njena glavna značilnost pa je bilo zvesto upodabljanje šeg in navad grškega ljudstva sprva na vasi, kasneje pa tudi v mestu. Itografi so pisali predvsem pripovedi in kratke zgodbe, le redko pa so se lotevali romanov. V nekaterih književnih delih te usmeritve lahko prepoznamo vplive naturalizma in zrelega realizma, toda večinoma so itografi v svojem pisanju ostajali na bolj površinski, narodopisni ravni, ne da bi si, na primer, posebej zastavljali naturalistična vprašanja o človekovi determiniranosti in dednosti ali se poglabljali v psihologijo likov. Od začetka 20. stoletja je grška kritika začela na šolo itografije gledati močno nenaklonjeno prav zato, ker so ji očitali pomanjkanje kakršne koli psihološke globine in prepričljivosti likov, in kmalu je obveljala za preživeto tako v primerjavi z evropsko literaturo kot glede na družbene spremembe na prelomu stoletja. K temu odklonilnemu odnosu sta verjetno pripomogla tudi razočaranje nad »veliko idejo« in potreba po novi definiciji grškosti. Naravnost izražena želja, da bi prerasli itografsko prozo, je bila ena od glavnih motivacij za izoblikovanje generacije tridesetih, razkol z neposrednimi predhodniki pa ena najpomembnejših postavk njihove samoprepoznave, ki je kasneje prodrla tudi v znanstvene teorije. Še danes pogosto odklonilni odnos literarnih teoretikov do itografske usmeritve je najverjetneje dediščina generacije tridesetih.

Prodor socialistične miselnosti v Grčijo je v njen kulturni prostor sicer prinesel nove ideje, vendar se to ni odražalo v razvoju modernejših literarnih zvrsti, saj ruska avantgarda v teh krajih ni padla na plodna tla. Levo usmerjeni pisci so izkazovali veliko večje zanimanje za politično kot za umetniško vrednost literature. ${ }^{4}$ Odločno so zavračali vsak individualizem in izpostavljanje subjekta - torej prav to, kar se je v grških literarnih krogih kmalu zatem povsem izenačilo s pojmom sodobne in umetniške literature - saj so vztrajali, da »se umetniško delo začne v skupnosti in se k njej spet vrača « ter predstavlja »objektivizirano zavest določenega družbenega razreda,$^{5}$ oblikovno in vsebinsko pa so ostajali tradicionalni vse do nastopa Janisa Ritsosa ${ }^{6}$ v tridese-

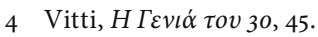

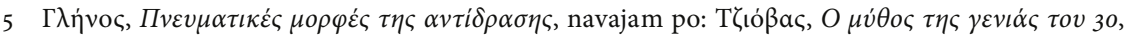
107.

6 Janis Ritsos (1909-1990) se skupaj s Kariotakisom, Kavafisom, Seferisom in Elitisom uvršča med največje grške pesnike 2o. stoletja. Prevajal je pesnike, kot so Aleksander Blok, Vladimir Majakovski in Nazim Hikmet. Poleg plodnega pesniškega opusa je zapustil še devet romanov in štiri gledališka dela, pisal pa je tudi članke in eseje. Sodeloval je pri odporu proti okupatorju med drugo svetovno vojno in bil kot član komunistične stranke po vojni večkrat interniran na grških otokih. 
tih letih. Med levo usmerjenimi pesniki je bil tedaj najbolj uveljavljen Kostas Varnalis, ${ }^{7}$ ki je bil v nekaterih pesmih skorajda bližji rembetiku ${ }^{8}$ kot literaturi, saj v njih upesnjuje prizore iz »kletnih tavern«, beznic, kjer se zbirajo in popivajo revni delavci, njegov verz ostaja tradicionalen, njegove rime pa izzvenijo nekoliko okorno.

$\mathrm{V}$ prozi pa je marksistična miselnost vplivala predvsem na spremenjeno topografijo in tematiko itografije. Panajotis Mulas kot vzorčni primer prozaista $\mathrm{z}$ začetka dvajsetih let izpostavlja Dimostenisa Vutirasa, ${ }^{9}$ simpatizerja levičarske ideologije in hkrati enega najbolj priljubljenih avtorjev tistega časa, ki je v glavnem objavljal krajšo prozo po časopisih in revijah, čeprav je pisal tudi romane, $\mathrm{v}$ svoje pripovedi pa je občasno vnašal elemente metafizike in znanstvene fantastike. Svet Vutirasovih likov je svet lumpenproletariata in malomeščanstva, svet revežev in malih prestopnikov. Odraža spremembe v strukturi grške populacije po množični selitvi prebivalstva $\mathrm{z}$ vasi v mesto, nastanku prostranih naselij okrog Aten in Pireja ter povečanju števila brezposelnih in revnih. Temu sloju družbe se je po letu 1922 pridružil še poldrugi milijon maloazijskih izgnancev. Rezultat vseh teh selitev je bila pestra kulturna zmes $\mathrm{z}$ močnim podeželskim, malomeščanskim in lumpenproletarskim nadihom.

Vutirasovi liki so statični: niso zmožni ukrepati, da bi si izboljšali življenje, in se nočejo vključiti v obstoječo družbo. Dogajanje proze tistih let se je tudi sicer preselilo v taverne in kletne beznice, osrednji liki pa so bili pogosto - kot pri Vutirasu in Varnalisu - ljudje iz najnižjih plasti in z obrobja družbe, ždeči v stagnaciji, v brezizhodnem svetu, ki se je utapljal v hlapih opija in alkohola. Predvsem pa je literatura sredi dvajsetih let kljub spremembi v dogajalnem prostoru večinsko ostajala itografska, ni še prišlo do dejanskega zasuka v načinu pisanja in upodabljanja realnosti.

\section{NOVA MISELNOST IN GENERACIJA TRIDESETIH}

Občutenje krize po prvi svetovni vojni se je v evropski književnosti izrazilo $\mathrm{v}$ podobah praznine, razgradnje in zavračanja preteklosti. Napočil je konec razsvetljenske vere v neprekinjeni napredek človeštva. Stara hierarhija vrednot in razredov se je začela sesedati, do besede pa so prišle družbene skupine, ki

7 Kostas Varnalis (1884-1974) je bil pesnik in novinar, ki je pisal pesmi in lirične drame z revolucionarno vsebino.

8 Ljudska zvrst glasbe, ki se je izoblikovala najprej okrog večjih pristanišč in postala kasneje priljubljena po vseh večjih grških mestih, vključevala pa je petje in instrumentalno spremljavo. Svojo dokončno obliko, v kakršni ga poznamo danes, je rembetiko privzel prav v obdobju po maloazijski katastrofi, ko so ga prišleki iz Turčije obogatili in močno spremenili z lastno glasbeno tradicijo. Rembetiko se je tematsko povezoval predvsem z beznicami, erotiko, drogami in težkim življenjem na obrobju družbe, njegovi pevci so se neredko med seboj spopadali z noži in omamljali z opijem. Peli so ga tako moški kot ženske.

9 Dimostenis Vutiras (1872-1958) se je rodil v Istanbulu, vendar je vse življenje preživel v Grčiji, bil je eden izmed najvidnejših prozaistov obdobja med obema vojnama. 
so bile prej nevidne, kot ženske ali delavci. Religija, ljubezen do domovine, družbeni sistem, vsi ti pojmi v novi književnosti postanejo ambivalentni. Modernistična književnost odpira prostor polifoniji, mnogosti zornih kotov. Skuša upodobiti družbo v njeni večplastnosti in mnogopomenskosti. Tehnologija postane nova tema literature, simbol novega načina življenja in napredka, kot v Orlandu V. Woolf ali pri futuristih.

Grčijo so odmevi sprememb v evropski literaturi, tako na zahodu kot na vzhodu, zaradi dolga desetletja trajajočih ozemeljskih bojev, vojne, ki se je nadaljevala še po koncu prve svetovne vojne v Evropi, in s tem povezane močno nacionalistične usmeritve $\mathrm{v}$ državi, ki je skorajda programsko spodbujala tudi temu ustrezno književnost, dosegli z določeno zakasnitvijo. Kljub temu pa so se jih napredneje misleči, pogosto mlajši avtorji željno oprijeli. V tradicionalistično, okostenelo Grčijo so nove ideje prodirale tako z zahoda, skupaj z mladimi, ki so študirali v Evropi in so se zdaj vračali v povečano domovino, kot z vzhoda, od koder so priseljenci iz Male Azije prinašali drugačno, neznano kulturo in doživetja.

Angelos Terzakis, ${ }^{10}$ predstavnik literarne generacije tridesetih in skupaj z Jorgosom Teotokasom ter Andreasom Karandonisom eden njenih poglavitnih teoretikov, je situacijo in razpoloženje med mladino $\mathrm{v}$ literarnih krogih $\mathrm{v}$ začetku dvajsetih let opisal tako:

Bilo je večplastno: literarno podzemlje in nekaj majhnih pritličnih tiskarnic. Književnost in družbena vstaja. Nepomembna glasila mladih, brez kupcev, in komunistični letaki. Domača književna tradicija in vdor ruskih pisateljev. ${ }^{11}$ Prvi ljubezenski zanosi in pretepanje v kleteh policije. 1917 je bilo komaj včeraj; v medijih tiste dobe so njegovi odmevi prihajali z zamudo. /.../ Dolge povorke beguncev so vsak dan počasi, žalobno stopale mimo zamegljenih šip tavern, kjer smo bedeli med neskončnimi pogovori in si prizadevali, da bi našli smerokaz v svetu, težišče v življenju. /.../ Blagor tem, ki so tja prišli leta 1930 in uzrli ter z lahkotnim kritiziranjem oblatili naš neizrečeni pogled na svet. $Z$ ladjami so se vračali iz tujine, zloččeni, polikani, in bili so buržuji: nikoli se niso soočili z nobenim življenjskim problemom; imeli so ambicije, zahteve, ne da bi kar koli žrtvovali. ${ }^{12}$

Želja po naprednem in avantgardnem se je povezovala s pojmi mladosti in življenjske energije, moči, zdravja, želje po ustvarjanju novega, vsega tistega, kar naj bi bilo edini antidot za deziluzijo in malodušje. $V$ začetku tridesetih let so se tako v literarni areni začeli uveljavljati mlajši pisatelji, pesniki in esejisti, ki jih je družila želja po prenovitvi duhovnega življenja v Grčiji po burnih političnih in idejnih preobratih na začetku 20. stoletja in po ustvarjanju književnosti, ki bi

\footnotetext{
10 Angelos Terzakis (1907-1979) je pisal pripovedi, romane in gledališka dela, pa tudi eseje. Bil je eden glavnih romanopiscev generacije tridesetih.

11 Dostojevskega in Gorkega.

12 Iz članka Angelosa Terzakisa v časopisu To vima (»Korak«), objavljenega 18. 1. 1967, navajam po: Vitti, $H$ TEviá tov $30,31$.
} 
odražala nove razmere in bi kanonu evropske literature dodala nekaj novega, izvirno grškega. Ti avtorji, ki se jih je proti koncu istega desetletja oprijelo poimenovanje generacija tridesetih, niso izoblikovali enotne šole pisanja, vendar pa so na grški literaturi pustili globok pečat: vanjo so vpeljali tako moderni roman kot pesništvo s prostim verzom in asociativnimi navezavami. Črpali so iz različnih sočasnih evropskih literarnih usmeritev, v njihovih delih lahko prepoznamo vplive modernizma, nadrealizma, zrelega realizma pa tudi avantgarde in futurizma, v grško književnost so vpeljali tehnike, kot sta notranji monolog in tok zavesti. Tematski poudarek je bil na čim celovitejšem prikazovanju stvarnosti in družbe, $\mathrm{z}$ vključevanjem novih oblik in področij "grškosti« (med pisci je bilo kar nekaj prišlekov $\mathrm{z}$ egejske obale), vse to pa $\mathrm{z}$ upoštevanjem novih spoznanj o človekovem duhovnem življenju (Bergson, Freud, psihoanaliza itd.). Zanimal jih je notranji svet junakov, vpeljali so modernistično tehniko menjavanja zornega kota $\mathrm{v}$ naraciji. Ne nazadnje $\mathrm{v}$ generacijo tridesetih sodita tudi nobelovca Jorgos Seferis in Odiseas Elitis. Gre za, kot pravi Dimitris Tziovas v študiji Mit generacije tridesetih ${ }^{13}$ enega izmed najbolj čaščenih in najbolj osovraženih književnih pojavov v zgodovini grške književnosti.

Vendar pa je definicija generacije tridesetih prav zaradi mnogosti in raznolikosti šol in ideologij, ki so vplivale na njene predstavnike, ostala nekako nedorečena. D. Tziovas, ki jo sam uporablja, hkrati opozarja na problematičnost uvrščanja $\mathrm{v}$ isto literarno smer pestre množice avtorjev $\mathrm{z}$ različnimi zanimanji, temami, tehnikami, izobrazbo in stikom z dogajanji v Evropi ter pripominja, da se nekateri »tipični predstavniki« generacije tridesetih sami ne strinjajo z uvrstitvijo vanjo. Tako na primer Nikos Engonopulos ${ }^{14} \mathrm{v}$ intervjuju za revijo Manna iz leta 1974 pravi: »Nikakršne zveze nimam z generacijo tridesetih, « v intervjuju iz leta 1978 pa celo zatrdi: »Nisem del neobstoječe generacije tridesetih. $\ll^{15}$ Podobno se je opredelil tudi Odiseas Elitis ${ }^{16} \mathrm{v}$ intervjuju iz osemdesetih let: "Zato pa se, kadar vidim, da me predstavljajo kot značilnega predstavnika generacije tridesetih, sprašujem, na kaj se pri tem opirajo. ${ }^{17}$ Po drugi strani pa se je Elitis udeležil obletnice generacije tridesetih, ki jo je organiziral J. Teotokas marca 1963 in jo v kolumni v časopisu To vima opisuje pisatelj Ilias Venezis. ${ }^{18}$

Skupaj s Tziovasom - in, kot bomo videli v nadaljevanju, Tziovas pri tem sledi J. Teotokasu - se lahko vprašamo, ali vezivo generacije tridesetih $v$ resnici ne izvira iz mita ali mitov, ki so jih izoblikovali tako sami pisci kot kritiki, ki

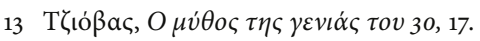

14 Nikos Engonopulos (1907-1985) velja za enega pomembnejših predstavnikov generacije tridesetih in grškega nadrealizma. Bil je slikar in pesnik, poleg tega pa je prevajal ter pisal kritike in študije.

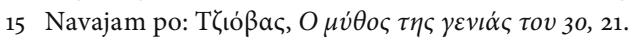

16 Odiseas Elitis (1911-1996) je eden izmed najznamenitejših grških pesnikov, prejemnik Nobelove nagrade l. 1979 in pred tem grške državne nagrade l. 1960. V njegovih pesmih se prepletajo elementi nadrealizma s posnemanjem ljudskega pesništva, uporabljal je tudi tehniko kolaža.

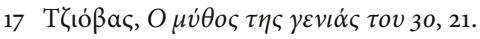

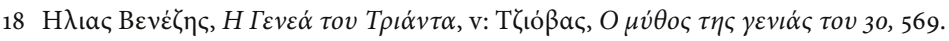


so se $\mathrm{z}$ njimi ukvarjali. ${ }^{19}$ Takšno vprašanje je toliko bolj umestno, ker so bili pripadniki generacije tridesetih posebej močni v teoretičnih spisih o literaturi (kritikah, esejih, člankih) in so med seboj korespondirali o književnosti. Teorija in praksa sta se razvijali z roko v roki. Zato ni presenetljivo, da so se pripadniki generacije tridesetih najprej začeli zbirati okrog literarnih revij. Vitti na nekem mestu generacijo tridesetih celo definira kot »krog mladih in njihovih

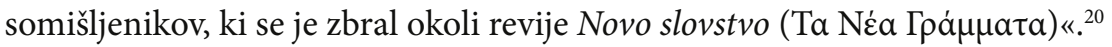

Med prvimi je leta 1928 začela izhajati revija Dih (Пvoฑ́), ${ }^{21}$ v uvodniku prve številke, ki ima naslov Apologija, pa so jasno predstavljeni cilji urednikov: ${ }^{22}$ hoteli so pomesti z zastarelo miselnostjo in izčrpanim duhovnim življenjem ter se otresti spomina na grške poraze. Stare sanje so propadle, oni pa so hoteli zgraditi nov svet ter popeljati mlade, $\mathrm{z}$ njimi pa cel narod, v novo, 20. stoletje. Zahtevali so duhovno osvoboditev in duhovno revolucijo. ${ }^{23}$ Evangelios Sakas ugotavlja, da so, polni vere v moč mladosti, poskušali zavestno in enotno prenoviti književno produkcijo v Grčiji. ${ }^{24}$

Kmalu zatem, jeseni 1929, je izšel tekst, ki je kasneje obveljal za neformalni manifest generacije tridesetih. To je bil esej Svobodni duh Jorgosa Teotokasa, ki še danes predstavlja izhodišče za najvidnejše preučevalce tega literarnega gibanja. ${ }^{25}$ Hkrati gre za prvi esej na grških tleh, ki je izšel v knjižni obliki. Takoj po objavi je izzval burne odzive med literati in kritiki. Odiseas Elitis se v Dnevniku nekega desetletja spominja:

Prisotna je bila energija in Grčija je bila prav gotovo v vzponu. V književnosti je zasvitala generacija tridesetih. Ob večerih smo, ko smo se vračali s stezic Likavitosa, "še sveži od poljubov deklet«, držali v rokah Svobodni duh Jorgosa Teotokasa, in nismo vedeli, ali naše srce tako razbija za Književnost ali za Ljubezen. ${ }^{26}$

Seferis pa v pismu iz leta 1931 o Svobodnem duhu zapiše: »Kajti to je /.../ naš teoretični credo in rad bi se ga naučil na pamet. « ${ }^{27}$

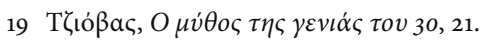

20 Literarna revija Novo slovstvo je izhajala v letih 1935-1940 ter 1944-45 pod taktirko Andreasa Karandonisa, literata ter enega izmed vplivnejših kritikov tistega časa. V njej so objavljali najznačilnejši predstavniki generacije tridesetih.

21 Revija Dih je izhajala od oktobra 1928 do prve polovice 1930. Objavljala je izvirno prozo in pesmi, prevode, literarne kritike ter pisma.

22 Uvodnik je anonimen, podpisan je z Dih, vendar ga je najverjetneje napisal A. Terzakis, ki je bil skupaj z J. Teotokasom in A. Karandonisom eden izmed glavnih teoretikov omenjene generacije.

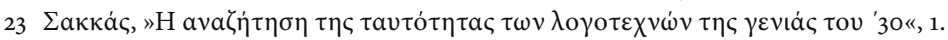

24 Prav tam, 9.

25 Posebno poglavje so mu v svojih študijah o generaciji tridesetih posvetili tako D. Tziovas kot M. Vitti in P. Mulas, ki ga vsi obravnavajo kot izhodiščni tekst za razpravo o »ideologiji« te generacije.

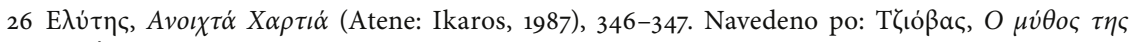

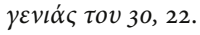

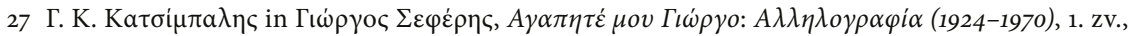

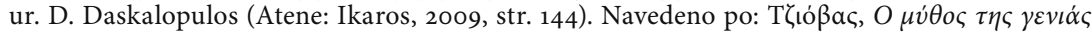
Tov 30,23 . 


\section{SVOBODNI DUH JORGOSA TEOTOKASA}

Romanopisec in esejist Jorgos Teotokas se je rodil leta 1906 v grški družini v Istanbulu, kjer je živel do leta 1922, vse do prisilne izmenjave prebivalcev med Grčijo in Turčijo. Čeprav je bil Istanbul tedaj še izvzet iz obvezne izmenjave, so se tega leta preselili v Atene. Tam je najprej doštudiral pravo, nato pa se je leta 1927 odpravil v Pariz, kjer se je izobraževal iz prava, zgodovine in filozofije, ter naslednje leto še $\mathrm{v}$ London, kjer se je ukvarjal $\mathrm{z}$ angleškim pravom in filologijo. Leta 1929 se je vrnil v Atene, kjer je delal kot odvetnik. Od leta 1929 je Teotokas pisal politične in teoretske članke za različne vplivnejše grške časopise, v letih 1933 in 1936 je izdal prvi in drugi zvezek svojega prvega romana Argo, leta 1938 pa roman Demon. Izdal je še tri romane, številne eseje, nekaj popotniških dnevnikov, mdr. po Ameriki, Sovjetski zvezi, Siriji in Iranu, ter dve zbirki dram. Kot avtor številnih teoretičnih tekstov in predavanj, posvečenih generaciji tridesetih in »novi književnosti«, velja za njenega najbolj uzaveščenega predstavnika.

Esej Svobodni duh ni napisan z znanstvenega stališča in, strogo vzeto, ni manifest nobene šole, čeprav so mu kasneje zaradi njegovega kultnega statusa in jasne predstavitve novih tendenc $\mathrm{v}$ književnosti in misli pripisali težo manifesta: avtor, ki ga je objavil pod psevdonimom Orestis Digenis, je uvodoma poudaril, da njegov namen ni vzpostaviti književnega ali literarnoteoretskega gibanja, temveč nagovoriti grško mladino in jo spodbuditi, naj si poišče lastni način umetniškega izražanja. Idej ne izraža organizirano, temveč pusti misli, da se razvija ciklično in naravno teče od ene teme k drugi, k posamičnim temam se vrača na različnih mestih in jih obravnava $\mathrm{v}$ različnih kontekstih. Ta sproščeni način pisanja lahko povežemo s Teotokasovimi stališči o eseju kot zvrsti. Književni esej je zanj ustvarjalna zvrst, enakovredna drugim zvrstem umetniške besede, in mora jo zaznamovati avtorjev duh, izražati mora slog, notranje življenje in občutljivost, esejist mora zavzemati osebno držo do tem, ki jih obravnava. Teotokas je za eno izmed dveh zvrsti, ki ju je v Grčiji zares razvila šele generacija tridesetih, ob romanu štel prav esej. ${ }^{28}$

Ker je torej Svobodni duh v skladu $\mathrm{z}$ avtorjevimi prepričanji izraz njegove subjektivnosti, postane $\mathrm{v}$ nekem smislu tudi politična izjava, ostra zavrnitev tako nacionalizma kot marksizma $\mathrm{v}$ imenu liberalizma. $\mathrm{V}$ njem lahko najdemo celo pohvalo pomembnega grškega politika Elefteriosa Venizelosa. Vitti opozarja, da esej izraža klasične poglede dobronamernega liberalca iz meščanskega razreda, dejstvo, da ni na lastni koži občutil maloazijske katastrofe, pa mu omogoča optimistični pogled na prihodnost. ${ }^{29}$ Problematiko lahko predstavlja z zahodno optiko ne le zaradi svojega študija v tujini, temveč je že $\mathrm{v}$ Istanbulu obiskoval francosko gimnazijo in bil torej dobro seznanjen tako s francosko miselnostjo kot literaturo in jezikom.

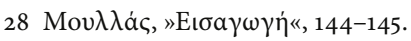

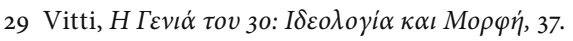


Tziovas Svobodni duh poimenuje »manifest individualizma«. Ta spis opiše kot najbolj »mladostno vihrav«, najbolj »usmerjen k Evropi« in najbolj »radikalen v odnosu do zgodovine«, kar jih je kdaj izšlo v Grčiji. Teotokas v njem ne nastopi kot častilec in posnemovalec evropske literature, temveč celo kritizira svoje sodobnike, ki so med študijem v tujini postali privrženci te ali one umetniške šole. Zanj je bistvena umetnikova individualnost in prizadevanje za lastni izraz. Osebna svoboda je prizma, skozi katero opazuje narodni značaj, politiko, roman in književno tradicijo. Ravno zaradi vere v značaj in duha posameznika pa se v spisu posveča tudi iskanju velikih osebnosti v grški literarni tradiciji in politiki. V svojem liberalnem svetovnem nazoru si družbo predstavlja kot skupek samostojnih oseb, ki razmišljajo in se odločajo po svoji glavi. ${ }^{30}$

Generacija tridesetih ni agitirala za prelom s preteklostjo v absolutnem smislu, bolj jim je šlo za integracijo starega z novim. V tem smislu lahko razumemo njihovo ukvarjanje s prevrednotenjem starejših pesnikov (nekaj takega kot obrat moderne $\mathrm{k}$ Prešernu) in celo iskanje vzornikov, pa tudi zanimanje za ljudsko slovstvo in ne nazadnje »grštvo«. V Svobodnem duhu (str. 70) Teotokas zapiše, da bo nova estetika črpala iz podob, kot je letalo nad Partenonom, ki ustvarjajo »novo harmonijo«.

Svobodni duh generaciji tridesetih ne predstavlja ustvarjalnega vodila. Omenjajo predvsem, da jih je navdihoval $\mathrm{z}$ voljo po razdoru s preteklostjo in s svojim nalezljivim mladostnim entuziazmom. ${ }^{31}$ Teme, o katerih spregovarja Teotokas, so stanje tedanje grške literature v primerjavi s sočasno evropsko, odnos grške kritike do grške književnosti, vloga in pomen književnosti nasploh in smer, v kateri uzira prihodnji razvoj grške literature. Vodilna ideja vseh štirih poglavij (Sprehod skozi Evropo, Narodov značaj, Itografija in Pogoji za pravo avantgardo) je, da je grška misel, kot jo izražajo grška literatura (Teotokas se tukaj ukvarja predvsem s prozo, ki se mu zdi potrebnejša prenove), literarna kritika in filozofija, postala dogmatična in jalova. Morala bi se osvoboditi kletke lastne preteklosti, da bi ustrezala potrebam moderne dobe.

V prvem poglavju, Sprehodu skozi Evropo, Teotokas izraža prepričanje, da duhovno in intelektualno življenje njegovega časa stagnirata, ker grški intelektualci ne razumejo popolnoma sodobnih evropskih tendenc in jim ne sledijo, hkrati pa tudi sami ne ustvarjajo ničesar novega. Evropa je celota, sestavljena iz med seboj razlikujočih se elementov, primerljiva s koncertom, med katerim različne melodije niso vedno ubrane, pa se vendar istočasno zlivajo v »višjo simfonijo«. Če odmislimo umetne razlike med narodi, bomo ugotovili, da se v svojem bistvu vedno gibajo bolj ali manj v isto smer. Evropska misel stoji na istih temeljih, zato si intelektualci različnega izvora delijo kulturo in ideje, ki so v svoji srži enake: žene jih skupna želja, da bi odkrili univerzalne resnice o ljudeh.

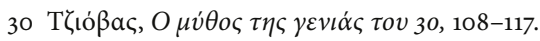

31 Prav tam, 119. 
Toda Teotokasovi grški sodobniki niso pravi Evropejci (kar je v Teotokasovih očeh izjemno negativna značilnost). Malomeščanski so in zaplankani, saj niso pripravljeni preseči lokalnih delitev in doumeti ideje Evrope kot ene same, velike celote. Raje z nepopustljivo vnemo sledijo kakšni miselni šoli, najraje kateri od tistih, ki jih Teotokas poimenuje "geografske« (npr. francoska, nemška, ruska), in nepremišljeno zavračajo vse druge možnosti izbire (str. 9). Ne poskušajo odkrivati lastnih resnic in zato v skupno zakladnico evropske umetnosti in duhovnosti ne prispevajo ničesar edinstvenega. V povojni Evropi se poraja nova vrsta umetnosti in miselnosti, ki si jo evropske države delijo, kot so si delile vojna bremena. Toda Grčija je ostala na obrobju. Da bi se v duhovnem smislu razvila in postala bolj zares evropejska, bi potrebovala "svobodo misli«, »široka obzorja« in »bogastvo srca« (str. 11).

V Narodovem značaju Teotokas nadaljuje s kritiko poglavitne šole grške literarne kritike, češ da se zanima samo za preteklost in je dogmatična, literaturo poskuša ukalupiti v tog sistem pravil in zahtev. Grški literarni kritiki imajo ozka obzorja in trmasto spregledujejo, da so se časi spremenili. Napade predvsem enega izmed najvplivnejših literarnih kritikov svojega časa, Fotosa Politisa, ${ }^{32}$ kot reprezentativnega predstavnika stroke (str. 14-16). Čeprav se Fotos Politis ne boji primerjati del grške književnosti z evropskimi klasiki in s tem pred grške avtorje postavlja visoka merila, Teotokas njegova stališča označi za skrajna in zato za literaturo nevarna in omejujoča.

Fotos Politis naj bi verjel, da je vloga literature oživljanje tradicije in spodbujanje narodne zavesti. Vsa literatura bi se morala podrejati kalupu tako imenovanega narodnega značaja, vse drugo naj bi bilo zlagano in zgolj posnemanje tuje umetnosti. Čeprav je literarno delo izraz avtorjeve osebnosti, bi po Politisu moralo vedno izražati tudi značaj njegovega geografskega področja. Teotokas ugovarja Politisovi predstavi o nacionalnem značaju modernih Grkov, ki naj bi ga določali zgolj trije elementi: ljudsko pesništvo ter pesnika Dionisios Solomos ${ }^{33}$ in Aleksandros Papadiamantis. ${ }^{34}$ Ta izjemno ozki pogled na književnost ne omogoča nikakršnih razlik v osebnem okusu ali sodbah, medtem ko je značaj vsakega naroda heterogen, poln protislovij in spremenljiv. Dobro in potrebno je bolje spoznati preteklost svojega naroda, vendar je znanje o njej zgolj orodje, ki ga lahko uporabiš v korist narodovi sedanjosti in prihodnosti. Številni kritiki verjamejo v eno absolutno resnico, zapirajo svoj razum v ječo, namesto da bi sebi in drugim zagotavljali svobodo mišljenja. Primer takšne drže je tudi Kostas Varnalis, ki verjame, da bi morale biti edini vir literarnega navdiha zgodovinske teme (str. 21). Vendar niso samo kritiki

32 Fotos Politis (1890-1934) je bil vpliven režiser in teoretik gledališča pa tudi literarni kritik, ki je med letoma 1914 in 1934 objavil več kot tisoč člankov, kolumen in kritik.

33 Dionisios Solomos (1798-1857) velja za grškega narodnega pesnika, njegova Himna svobodi pa je od leta 1865 grška državna himna.

34 Aleksandros Papadiamantis (1851-1911) velja za enega od vodilnih grških pisateljev. Obravnavajo ga kot itografa, vendar v njegovih osrednjih delih prepoznamo jasen pečat naturalizma. 
krivi za ta način mišljenja, tudi nanje namreč vpliva splošno vzdušje dogmatizma v Grčiji v tem in prejšnjih desetletjih, zaradi česar bi si morale mlajše generacije ponovno priboriti miselno svobodo.

Drugi Teotokasov ugovor Politisu se glasi, da ta, ker zanika sedanjost, spregleduje popolnoma nove probleme, interese in potrebe svojih sodobnikov (str. 22). Dela Solomosa in Papadiamantisa so, preden so prešla v kanon grške literature, izražala živega duha časa in isto velja tudi za dela sodobnih avtorjev. Vsako mesto premore svojega lastnega duha: v ozračju Aten sta prisotni mladost in mladostnost. Mesto se naglo razvija in spreminja, vendar je intelektualno življenje njegovih prebivalcev moteno in preživlja krizo.

Politis in njegovi privrženci, enako kot marksisti in nacionalisti, od pisatelja in literature zahtevajo družbeno koristnost. Pri tem pa pozabljajo na tisto, kar Teotokas imenuje »demon «, to je iskro individualnega talenta in ustvarjalnosti, potrebno za nastanek pravega umetniškega dela.

Pozabljajo na Demona, pravzaprav sploh ne vedo zanj, kajti Demon živi v višji sferi od njihove, v katero se ne morejo privzdigniti ne njihove vsakdanje strasti ne njihov praktični duh niti njihova pritlehna logika. ${ }^{35}$

Umetnik je osebnost, ki jo napolnjuje obilje duhovnih moči, sprosti pa jih lahko le tako, da jih »idealizira" s stvaritvijo umetniškega dela, ${ }^{36} \mathrm{ki}$ je potemtakem nekakšen čudež. Umetniških del ni mogoče preučevati na standardiziran način, saj je to zgolj poskus, da bi resničnost okrog nas prilagodili svoji percepciji le-te in zanikali njeno kompleksnost. Tak poskus je obsojen na to, da bo ostal na površini obravnavanega dela, saj ne zmore upoštevati njegove psihološke komponente, ki je vsakokrat edinstvena in je ni mogoče kategorizirati. V umetniškem delu je zaobsežena in uresničena neznanska obilica ustvarjalnih moči. Te moči in zamisli vedno sledijo lastni, svojstveni logiki, morali, ritmu itd., saj potreba po kreativnem izrazu ne preračunava, ali bo prinesla škodo ali korist. Umetniško delo je za svojega avtorja edini varni pristan.

Vendar pa je, nadaljuje Teotokas, res tudi to, da umetnik ustvarja, da bi se razdajal svojim bralcem. Umetniško delo je dar družbi. Vsak pisatelj piše z namenom, da bi ga brali. Četudi pisatelj poveže ustvarjalne moči v svojem delu $\mathrm{z}$ nekaterimi racionalnejšimi ideološkimi in filozofskimi konteksti in cilji, ti še vedno ne predstavljajo glavnega razloga za nastanek dela; obstajajo preprosto na drugi ravni.

35 Svobodni duh, 32. Ko sem se v prevodu odločila za besedo »demon" in ne »daimonion«, sem

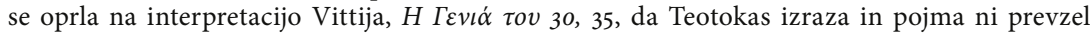
naravnost od Sokrata, temveč iz francoščine. V francoskem okolju se je »demon " pojavljal kot naslov številnih knjig in drugih spisov, označeval pa je človekovo navdihnjenost ter njegovo zmožnost za napredek in razvoj. Ta interpretacija se mi zdi prepričljiva tudi v kontekstu Teotokasovega romana Demon.

$36 \mathrm{Na}$ tem mestu lahko zasledimo vpliv freudistične misli. 
Morda je tvegano, se vprašuje Teotokas, vse to govoriti grški mladini, saj so v danem trenutku najbrž najpotrebnejši učitelji, inženirji in drugi preudarni mladi strokovnjaki? ${ }^{37}$ Toda teh je v Grčiji dovolj; to, česar ni, je sveti ogenj ustvarjalnosti, saj v zadnjih letih v tej deželi niso ustvarili ničesar veličastnega niti lepega (str. 35).

V poglavju Itografija Teotokas ponovno potoži, da sodobna Grčija ne prispeva ničesar vrednega $\mathrm{k}$ intelektualnim in duhovnim razsežnostim Evrope. Čeprav so se Grki že pred dobrim stoletjem osvobodili izpod turškega jarma, v tujini ne berejo modernih grških pisateljev. Morali bi preučiti grško preteklost, da bi odkrili - in zatem odpravili - šibke točke grške književnosti. Nikakor ne bi smeli mednje šteti sprejemanja tujih vplivov, težava je, prav nasprotno, v tem, da grška literatura sama ni vplivala na književnost izven svojih meja.

Za to po Teotokasu niso krivi pesniki. V pesništvu ima veliko težo izvorna muzikaličnost vsakega jezika, zato je predvidljiva usoda pesnikov iz malih dežel, da se ne morejo široko uveljaviti v svetu. Grčija, kot pravi, premore veliko odličnih pesnikov, na primer Palamasa, Griparisa, Mavilisa ali Solomosa (str. 38). Ugotovimo lahko, da je Teotokasa v tem pogledu zgodovina kmalu postavila na laž, saj so (ob Kazantzakisu) predvsem grški liriki tisti, ki so najširše zasloveli po svetu.

Šibki člen naj bi bili pisci proze. Teotokas najbolj ceni Emanuela Roidisa, Joanisa Psiharisa in Iona Dragumisa (str. 38). Poimenuje jih pisce-kritike, s čimer želi povedati, da so se osredotočili bolj na preverjanje in vrednotenje idej, nacionalnega značaja in v Dragumisovem primeru lastnega Jaza kot pa na čisto ustvarjanje. Ceni jih kot duhovne voditelje, ki so posvetili vse svoje ustvarjalne moči temu, da bi v Grčiji omogočili reforme. Namesto očitkov, da niso ustvarili del, enakovrednih tistim iz evropske literature, bi jim grško ljudstvo moralo izkazovati hvaležnost. To pa ne velja za sodobne noveliste in redke romanopisce, ki želijo biti umetniki in ustvarjalci, pa kljub temu pišejo samo plitve zgodbe, lahkotno čtivo, s katerim v kanon grške literature ne prispevajo ničesar novega. To so pisci, ki ustvarjajo itografijo, ki jo Teotokas poimenuje »fotografska šola" (str. 39). V petdesetih letih obstoja in prevlade itografije na grškem literarnem prizorišču so se razvile njene številne podzvrsti, kot so na primer itografija morja nasproti itografiji gora, itografija vaških skupnosti nasproti itografiji atenskega malomeščanstva, itografija velemesta in delavskega razreda. Vse te pojavne oblike se razlikujejo samo na zunaj, po izbiri scenografije, vendar ohranjajo skupno bistvo.

Tako imenovani itografi zvesto opisujejo življenje, kakršno se nam zdi, kadar ga zgolj opazujemo z distance, od zunaj, in si ne prizadevajo za nič več, enako pasivni so kot oko kamere. Zadržujejo se na površju dogodkov in ljudi, medtem ko pravi umetnik poskuša odkriti skrito bistvo živih bitij in stvari. Prav pod

37 Ta pomislek razkriva njegovo naklonjenost vladi E. Venizelosa, ki se je usmerjala v izgradnjo sodobnejše Grčije. 
površjem skrita individualnost, skrivna duša, je namreč tisto, kar nas očara in pritegne k določenemu kraju ali osebi ali umetnini. Če jo želi umetnik izluščiti, mora prestopiti meje tega, kar je vidno in razumljivo. Umetnik bralcem razkriva svetove in možnosti, ki jih predtem niso poznali, bogati njihova življenja in v njih budi duhovni nemir. Na novo ustvarja resničnost, da bi razkril njen smisel. Dober pisatelj proizvaja lastni slog pisanja in ritem, sledi lastni logiki in se ne podreja tej, ki mu jo vsiljuje družba; zato ne bi smeli nikdar nategovati sloga enega pisca na kopito drugega, kot bi želela že omenjena kritiška šola. V tem smislu ostajajo itografi popolnoma jalovi. Nekatera izmed njihovih del so lahko bralcu celo v užitek, vendar ne v duši ne v spominu ne zapustijo nobenega trajnega vtisa.

Teotokas trdi, da itografi verjamejo, da je njihova dolžnost do naroda poustvarjanje lokalnega kolorita in lokalnih posebnosti grškega podeželja in mest; občasno se to prelevi v edini namen njihovega pisanja. Njihova dela so - kot pravo nasprotje intenzivne individualnosti pravega umetnika - naravnost pretirano neosebna. Ker niso sposobni razlikovati med bistvenim in nepomembnim, je njihov slog nejasen in prenatrpan z odvečnimi besedami. Ne izražajo nikakršne intelektualne radovednosti in živahnosti duha: ne zastavljajo si nobenih vprašanj in ne iščejo nobenih odgovorov. Vse od časa Aleksandrosa Papadiamantisa niso razvili nobenih novih nazorov in so $\mathrm{v}$ glavnem miselno ujeti v preteklost. Tisti izmed njih, ki se približajo modernim vprašanjem, se raje zatekajo k dogmam marksizma.

Značaji, ki jih ustvarjajo grški prozaisti, so po Teotokasovem mnenju bledi in povprečni, v nobenem od njih ni intenzivnosti duše niti dejanj. Ostajajo površinski, tipizirani, da bi ustrezali sprejetim predstavam »dobrega«, »slabega«, »ljubosumneža«, »lenuha« itd. ali kakšnim teoretskim psihološkim konceptom; ti so lahko tudi pristni, toda pisatelj, ki pri oblikovanju svojih likov hlapčevsko sledi nekemu danemu sistemu pravil, teh ne bo zmogel oživiti niti jih narediti kakor koli prepoznavne. Grška literatura še vedno pogreša močnega, prepoznavnega protagonista s pristno osebnostjo, mislijo in strastjo. Tak lik bo zaživel lastno življenje onkraj literarne resničnosti, podobno kot sta ga zaživela Ana Karenina ali Don Kihot; predstavljal bo popolno uresničitev življenjskih moči in se bo $\mathrm{v}$ naših mislih razvil v polnokrvno, živo osebnost $\mathrm{z}$ značajem, izrazitejšim od povprečnega. Po njegovem mnenju so najmočnejši literarni liki v grškem kulturnem prostoru tisti iz gledališča Karajozisa, ${ }^{38}$ čeprav jih umetna literatura še ni izkoristila (str. 52).

Teotokas opiše splošno stanje grške literature v svojem času z besedo »anemija« (str. 53). Nekateri pisci so to stanje poskušali izboljšati, s tem da so v svoje delo uvajali nove koncepte, uvožene iz Evrope, na primer marksistično misel ali modernistični slog pisanja. Po Teotokasovem mnenju takšni postopki niso dovolj za prenovo duha grške literature, kajti ta boleha za notranjim

38 Gre za komično gledališče senčnih lutk z naborom stalnih likov, od katerih je glavni lik revnega sleparja Karajozisa. Ta ljudska zvrst je razširjena tudi drugod po Balkanu in v Turčiji. 
problemom. Grškega intelektualnega življenja ne more obnoviti kopiranje tujih modelov in idej, saj si mora vsak umetnik poiskati lastno pot in si prizadevati, da bi našel lastni način izražanja.

Grški intelektualci so se znašli na točki, ko občutijo žgočo potrebo po kakovostnejši prozi. Ne samo zato, da bi zasedli enakovredno mesto v evropski skupnosti, temveč predvsem zato, ker potrebujejo pravo duhovno hrano. Preživljajo težke in resne čase, zato bi morali ustvarjalci tudi literaturo jemati resneje. Mladi pisatelj bi si moral, če ima pravi dar, prizadevati, da bi duhovnemu življenju v Grčiji zastavil višje standarde. Obravnavati bi moral globlje in pomenljivejše tematike, jezik pa rabiti bolj premišljeno in spretneje. Mladina se mora odtrgati od tradicije in poiskati nove cilje za novo generacijo.

V Pogojih za pravo avantgardo Teotokas podrobneje analizira splošno krizo grškega intelektualnega življenja. Začne s trditvijo, da se široki krogi ljudi zavedajo kritičnega stanja grške umetnosti in filozofije. Povojna Evropa ni bila več enaka kot prej. Vojna je spremenila njene vrednote, moralo, mišljenje in čutenje. Pretrgati je bilo treba vezi s starim sistemom in s preteklostjo, zaradi česar so se pojavila gibanja kot dadaizem. V Evropi Teotokasovega časa se, potem ko je bilo dekonstruirano staro, nemir v sferi intelekta nadaljuje, pojavljajo se nove oblike in načini izraza, opazna so nova literarna gibanja in kakovostna literarna dela. Ta doba je nestalna in nemirna, toda tudi plodna. Toda medtem ko kriza drugod v Evropi izvira iz presežka sveže ustvarjalne energije, je v Grčiji, ki jo je izčrpalo deset let vojne, nasprotne narave in jo je mogoče opisati z naslednjimi opažanji (str. 59):

Prvič, literatura je zamrla, njena kritika pa postala militantna. Obstajajo izjeme kot Nikos Kazantzakis, Trasos Kastanakis ali Fotos Kondoglus, vendar gre za osamljene primere.

Drugič, med Grki ni najti neodvisne filozofske misli. Zanašajo se na to, s čimer jih pitajo bodisi z Zahoda ali iz Rusije ali kar so podedovali od Bizanca. Grška mladina, ki išče resnico in odgovore na življenjska vprašanja, zlahka podleže fanatikom ideologij, nacionalistom in komunistom, ki ji ponujajo preprosto razlago sveta, ni pa kritičnih mislecev, ki bi ovrgli trditve obojih, saj kritična misel ne more cveteti v okolju, kjer ji odrekajo svobodo.

Ne nazadnje pa je pomemben dejavnik tudi ravnodušnost širše družbe. Nihče se ne trudi, da bi kultiviral okus grškega ljudstva, ki prebira lahkotno literaturo, s katero zadovoljuje potrebe po bežnem razvedrilu. To je po Teotokasu vredno obžalovanja, saj je grški narod posebno bister, živahen in ga privlači vse, kar je lepo.

Seveda bi za krizo lahko obstajali tudi drugi razlogi. Nekateri krivijo vlado, toda od vladnih ustanov, kot meni Teotokas, ni mogoče pričakovati, da bodo skrbele za razvoj duha. Njihova dolžnost je opazovati spremembe v literaturi in jo ohranjati v arhivih. Uslužbenci takšnih ustanov niso ljudje širokih obzorij in svobodnega duha. Edina dolžnost vlade je poskrbeti za boljši izobraževalni sistem in pustiti pesnikom njihovo svobodo. 
Grčija je, kot se zdi, po vojnih tegobah in bliskovitih spremembah, ki so vojni sledile, izgubila veličino svojega duha. Pred vojno je bila grška družba majhna in izolirana, glavni problem grških intelektualcev pa je bila razprava o jeziku. ${ }^{39}$ Pretežno so se zanimali za zgodovino, toda iznenada se je svet okrog njih skokovito pognal naprej; izgubili so svoj položaj in sposobnost kar koli ustvarjati. Velik del mlajše generacije je pobrala vojna. Številne smrti in veliki poraz so povzročili, da se je grški narod vdal depresiji, razočaranju in nostalgiji, in vsa ta stanja se odražajo v grški poeziji in prozi. Toda prav to je lahko najboljši trenutek, da se pojavi nova vitalna moč. Grški narod je dosegel najnižjo točko in zdaj bo sledil preobrat.

V grški literaturi je bilo vedno nekaj pesimističnega, meni Teotokas, neka skrivna navezanost na smrt, že vse od ustne pesniške tradicije. Pesnik Konstantinos Kavafis je v njegovih očeh utelešenje njenega melanholičnega duha, saj sta poglavitni občutenji v njegovem pisanju naveličanost in objokovanje neizpolnjenega življenja. Iz tega razloga ga ne bi smeli zamešati z literarnim pionirjem, na katerega Grčija čaka, ne glede na njegovo pesniško moč. Kavafis je vrh in konec neke dobe, v tem, kar je naredil, ga ni mogoče preseči, vendar ni prinesel sape svežine in vitalnosti, ki je potrebna v novem času. Mnogo bolj se je Teotokasovemu idealu približal Ion Dragumis, ${ }^{40}$ moderen in energičen pisec, čigar slog in ideje je imel za napredne in zato nerazumljene (str. 69-70). Teotokasovo navdušenje nas lahko preseneti, saj sicer zavrača nacionalizem v književnosti, Dragumis pa je bil, recimo v delu Kri mučencev in herojev, politični pisatelj in propagandist. Verjetno ga je prepričal z zametki notranjega monologa v svojih romanih in ničejanskimi vplivi.

Grška literatura, ponovi Teotokas v zaključku eseja, zdaj morda res stagnira, vendar se pod površjem skriva obljuba svetlejše prihodnosti. Veliko je samooklicanih duhovnih vodij, ki menijo, da vedo, kaj je prav, in poskušajo avtorje tlačiti v kalupe, ki se zdijo primerni njim. Toda mladina bi se morala osvoboditi okovov preteklosti. Vse, kar morajo narediti, je, da ne sledijo slepo svojim učiteljem in starejšim, pač pa uporabljajo lastno glavo in ustvarijo lastni svet in lastno literaturo.

\section{JORGOS TEOTOKAS KOT TEORETIK IN AVTOR GENERACIJE TRIDESETIH}

Esej Svobodni duh je temeljno zaznamoval vse nadaljnje preučevanje generacije tridesetih let. Čeprav v resnici ni prinašal nobene izvirne ideje, kar je

39 Razprava o tem, ali naj bo grški uradni in knjižni jezik sodobna grščina (dimotiki) ali umetno antiki približana katarevusa.

40 Ion Dragumis (1878-1920), grški diplomat, politik in romanopisec. Bil je po eni strani nasprotnik osvajanja v Turčiji in je predlagal dogovor, po drugi strani pa je bil zagrizen propagandist ozemeljskega boja v Makedoniji. Kasneje se je iz patriota nacionalista prelevil v socialista oziroma anarhista, leta 1920 pa je bil umorjen iz političnih razlogov. 
jasno že, če njegove postulate primerjamo s postulati skupine okoli revije Dih, velja, da gre za najsistematičnejši pregled tistega idejnega sklopa, ki je vplival na razvoj moderne literature v Grčiji. Izražal je duha časa v kapsuli. Kultni status je obdržal do danes, le da se je iz književnega mainstreama preselil v teoretičnega. Ko beremo Teotokasa, skorajda dobimo vtis, da kasnejša literarna zgodovina pri definiranju generacije tridesetih kot neke predpostavljene ali realne celote nikoli ni prišla dlje od ponavljanja trditev iz Svobodnega duha.

Svoje poslanstvo je videl v skrbi za razvoj sodobne literature. Kot se zaveda sam in kot potrjujejo tudi pričevanja njegovih sodobnikov, je prav on duhovni oče poimenovanja in koncepta generacije tridesetih. V svojem dnevniku $\mathrm{z}$ 22. 11. 1947 je takole povzel svoje predavanje z naslovom Literarna generacija tridesetih:

Tega ne govorim javno, ampak dobro se spominjam, da sem prvi uporabil izraz generacija 1930. Zavestno in hote sem dlje časa poskušal ustvariti in razširjati mit tridesetih in zdaj vidim, da se mi je nekaj le posrečilo. Namen mojega predavanja je bil dokončno uveljaviti ta mit. To počnem, ker verjamem, da so takšni miti nujni za duhovno življenje, ki je tako dezorganizirano in nestalno, kot je naše /.../

Če me spomin ne vara, sem prvič uporabil izraz génération de 1930 v nekem splošnem pregledu sodobne grške literature, ki sem ga pred leti objavil v reviji Europe. Tako se je, podprt z bliščem Pariza, izraz tem bolj uveljavil. ${ }^{41}$

$\mathrm{V}$ osnutku istega, nikdar objavljenega predavanja pa o istem terminu zatrdi, da se je pojavil skorajda spontano in da njegova vsebina ni jasna. Po njegovih besedah gre za splošni vtis, ki sta ga ustvarila pojavitev več mladih pisateljev hkrati in neki novi ton v literaturi. Gre za, kot pove naravnost tudi v predavanju, »mit generacije tridesetih ${ }^{4}{ }^{42}$

Teotokas v omenjenem osnutku predavanja že suvereno operira s pojmi, ki se vztrajno pojavljajo $\mathrm{v}$ vseh kasnejših študijah na to temo: rojstvo nove literature iz sivega obupa Grčije po propadu velike ideje, vplivi zahodnih romanopiscev, kot so Dostojevski, Proust, Gide, Joyce, Huxley, Lawrence, in ob njih še Freuda; sprejemanje vse raznovrstne grške literarne tradicije in njena sinteza z evropsko; iskanje lastnega izraza, razvoj romana in prostega verza, ki je podvržen samo notranji harmoniji besed in podob. Temu seznamu kasnejša literarna zgodovina ni dodala tako rekoč nič. To daje vtis, kot bi v trenutku predavanja od delovanja generacije tridesetih minila že dolga desetletja. Jasno postane tudi, da levji delež teorije o generaciji tridesetih izvira naravnost od njenih predstavnikov samih. Teotokasova raba izrazov "mit" in "generacija» na mestu, kjer bi pričakovali govor o umetniški šoli, pa osvetljuje vzroke za nejasnosti glede enega osrednjih terminov grške literarne zgodovine.

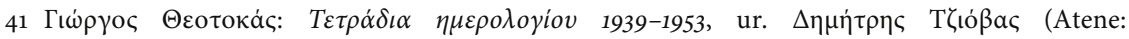

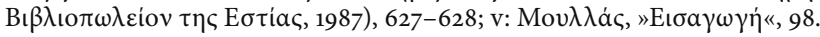

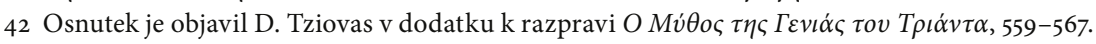


S svojim "mitom " so povezali tudi nekatere mitske, "prelomne" letnice. Razen leta izida Svobodnega duha je tu še leto 1933 kot začetek obdobja romana, ko je v Grčiji izšlo kar sedem vidnejših romanov avtorjev mlajše generacije, med njimi klasična dela, kot so Oficir Ljapkin M. Karagatsisa, Argo J. Teotokasa in Učiteljica z zlatimi očmi S. Mirivilisa. Roman je tako rekoč čez noč postal osrednja prozna zvrst, ki je bila tudi v epicentru zanimanja literarne srenje: že istega leta je v reviji Idea Andonis Terzakis objavil esej o novogrškem romanu, Teotokas pa je v pomembnem članku Nova književnost (Idea, januar 1934) izpostavil, da se za »novo književno generacijo « začenja obdobje romana in eseja. ${ }^{43}$ Grški pisci so v romanu videli novo, napredno zvrst, ki po svojem bistvu ustreza moderni dobi, saj zaradi svoje prostornosti in prožnosti omogoča svobodno razvijanje več kot le enega lika z vsemi psihološkimi tančinami in prikazovanje družbe $\mathrm{v}$ njenih različnih spektrih. Andreas Karandonis ${ }^{44}$ je v Novem slovstvu leta 1938 o romanu dejal: „O grški pripovedi lahko izoblikujemo trdne sodbe, na roman kot izoblikovano zvrst pa gledamo nekam zadržano, čeprav so ga obdelovali in ga obdelujejo, še posebej danes, veliki talenti «. ${ }^{45}$ Te besede niso mišljene kot kritika zvrsti romana, temveč kot izraz teoretikove nemoči, da bi se o njem izrekal brez časovne distance.

Isti vplivni kritik v Uvodu v mlajše pesništvo, ki je izšel l. 1958, kot tretjo letnico posebnega pomena izpostavlja leto 1935. Tedaj izideta dve pomembni pesniški zbirki, Roman Jorgosa Seferisa in Plavž Andreasa Empirikosa, ki je v grško literaturo uvedel nadrealizem. Hkrati se je pojavila revija Novo slovstvo, v kateri je svoje prve pesmi objavil Odiseas Elitis. Karandonis tako govori o »letu-maternici«, v katerem so se dokončno razkrile nove značilnosti grškega pesništva v njegovi zreli obliki. ${ }^{46}$

Določanje prelomnih letnic je bilo nujno, če so hoteli ohranjati koherenco avtodefinicije. Osredotočenje na časovni okvir tridesetih let bi sicer težko utemeljili, saj so, na primer Stratis Mirivilis, pa tudi drugi, romane izdajali že v dvajsetih letih, Elitis pa je po drugi strani debitiral razmeroma pozno. Avtorji generacije tridesetih so redno objavljali še v petdesetih in šestdesetih, celo sedemdesetih letih 20. stoletja, le da se niso več počutili del istega gibanja.

Pripomnimo lahko še, da je Karandonis veljal predvsem za pronicljivega kritika pesništva, medtem ko se je Teotokas ukvarjal bolj s prozo in se je goreče zavzemal za izgradnjo grškega romana kot »kraljestva svobode«. Verjel je, da lahko na voljne strani romana preliješ različne ideološke pojave, vse vrste psihičnih razpoloženj in različne epizode iz življenja, ki jim je bil avtor kdaj

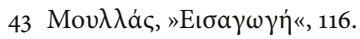

44 Andreas Karandonis (1910-1982), pisatelj, pesnik, pisec literarnih kritik in esejev, je imel sloves "kritika generacije tridesetih«. Skupaj z Jorgosom Katsibalisom sta ustanovila literarno revijo Novo slovstvo. V knjigi Prozaisti in proza generacije tridesetih je v literarno vedo dokončno uvedel pojem generacije tridesetih.

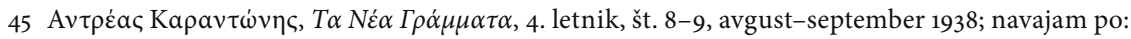

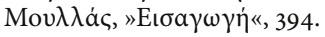

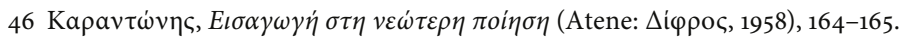


priča. Njegovi protagonisti naj bi bili odraz pojavov in tem, ki so Teotokasa zanimale v resničnosti. V prvem delu svojega prvega romana Argo je 1. 1933 zabeležil: »Argo nima osrednjega lika. Je izraz mnogih človeških stanj hkrati in mogoče (ne vem) njihovo upravičenje. $\ll^{47}$

V Argi je likov cela množica, fokus pripovedi pa se resnično ves čas spreminja. Naracija fluidno prehaja od enega lika do drugega, ti pa so med seboj včasih zelo rahlo povezani, zgodba poteka skoraj asociativno, po epizodah, ki imajo vsaka svojo temo in središče. Teotokas verjame, da je avtor zmožen povsem nepristransko prikazovati misli, prepričanja in občutke svojih junakov.

\section{»DEMON« ALI ISKRA NAVDIHA}

Preden je izšel Teotokasov naslednji roman, Demon, se je situacija v grški književnosti ponovno spremenila. Čeprav so pripadniki generacije tridesetih ustvarjali še dolga desetletja, se je že proti začetku naslednjega začel izgubljati občutek skupnega gibanja in delovanja. Že junija 1940 je Teotokas v svojem dnevniku zabeležil sledeči pogovor s Seferisom:

Najine ugotovitve: vse to gibanje tako imenovane generacije 1930 moramo imeti za končano. Tisti skupinski duh, ki bi potreboval vsaj dvajset let, da se dopolni, se tukaj ustavlja, živel je torej točno deset let. Zdaj Vojna prekinja vsako nadaljevanje, vsakdo ostaja sam vpričo svoje usode kakor na začetku. Nekaj smo začeli ustvarjati, ampak okoliščine nam niso bile naklonjene in razpadli smo na sredi poti. ${ }^{48}$

4. avgusta leta 1936 je v Grčiji nastopila diktatura Ioanisa Metaksasa, dogodek, ki je močno zamejil izrazne možnosti umetnikov, kar zadeva vprašanja družbene problematike, vzpodbudil pa je zatekanje v introspekcijo in upiranje pogleda v preteklost ter njeno idilično družbo. Metaksasov govor ob podelitvi literarnih nagrad maja 1940 zelo naravnost izraža njegov odnos do literature: "... črpajte navdih naravnost iz velikega, neizčrpnega vira, ki se mu pravi duša ljudstva. Vaši zgledi ne smejo biti potujčeni tipi, ki nimajo samostojnega življenja in je njihovo življenje posnemanje (mimesis), temveč morajo biti izvirno grški tipi in oblike. « ${ }^{49}$

V takšnem vzdušju je leta 1938 izšel roman Demon, za katerega je Teotokas še istega leta prejel nagrado atenske akademije Vikela. V njem slika zadušljivo kmečko okolje na otoku Petres, iz katerega kot neprijetno čudaštvo štrli družina Hristofidisovih. Njeni člani se zaradi svoje občutljivosti in nekakšne neoprijemljive težnje k višjim zadevam, zaradi nekultiviranih talentov za gledališče, matematiko in medicino v tej vasi počutijo ujete in se

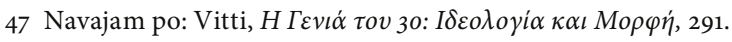

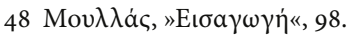

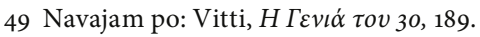


agresivno zaganjajo v ljudi okrog sebe kakor ptič v kletki. To, kar jih preganja in jim ne da miru, to potrebo po »nečem več«, pripovedovalčev prijatelj Romilos Hristofidis poimenuje »demon«. Vendar je edini, ki v življenju svoj dar dejansko razvije, najmlajši sin družine, saj edini premore dovolj trdnosti duha. Hristofidisovi so personifikacija Teotokasove vere v osebnega genija, kakršno izraža v Svobodnem duhu, na njih prikaže delovanje »demona«, ki pa je zavrt, njegova rast je onemogočena, in zato pripelje do tragičnega konca. V ravnanju stranskega lika Jeana Malcolma, kanadskega študenta arheologije, ki Romilosovo mlajšo sestro Ifigenijo uči angleščine in jo seznanja s Shakespearjem, pa vidimo odzven Teotokasove ideološke zapovedi, naj se mladi grški pisci vzorujejo po velikih evropskih klasikih, namesto da ostajajo zaprti v tesne meje domovine.

Kljub Teotokasovemu vztrajanju, da naj bodo liki psihološko pretanjeni, se Demon mestoma bere tudi precej sentimentalno in psihološko stereotipno. Vitti opozarja na obrat prej političnega pisatelja, avtorja romana Argo, k temam idiličnega podeželja, ki je neposredno povezan $\mathrm{z}$ nastopom diktature in dober primer, kako so bile ustvarjalne sile, ki so se zbudile v medvojnem obdobju, v kali zatrte. ${ }^{50}$ Nasprotno ga Teotokas sam v svojem dnevniku opiše kot »odsev nacionalne teme, ki je zatirana, izmučena in še nedokončana ustvarjalnost novejšega grštva«. ${ }^{11}$ Ta roman je torej razumel skorajda kot izraz upora, mi pa ga lahko vidimo tudi kot drugi, beletristični obraz njegovega Svobodnega duha, a tokrat $\mathrm{z}$ zaradi politične situacije zakritimi in zašifriranimi idejami.

\section{ZAKLJUČEK}

Generacijo tridesetih bi lahko opredelili kot premik v ustvarjalnosti mladih grških pisateljev in pesnikov, ki so grško književnost zavestno osvobodili spon nacionalizma. Njegov izraz je bila itografija v svoji najbanalnejši obliki popisovanja šeg podeželja in mesta, pa tudi ustvarjalnost propagandističnih avtorjev, denimo Penelopi Delta in Iona Dragumisa, katerih romani so bili predvsem sredstvo širjenja patriotizma. Pripadniki generacije tridesetih so s skupnimi močmi modernizirali grško književnost in vanjo uvedli različne evropske literarne tokove. Poimenovanje generacija tridesetih so skovali sami; prvi ga je uporabil Jorgos Teotokas in za njim Andreas Karandonis, slednjič ga je prevzela tudi literarna veda. Ker pa pisci, ki se v omenjeno "generacijo « uvrščajo, ne tvorijo enotne literarne šole, prihaja pogosto do ontoloških dvomov. K temu prispevajo tudi izjave posameznih pripadnikov. Zanimivo je, da je sam Teotokas generacijo tridesetih dojemal kot mit, ki se mu je zdel potreben za razvoj grške književnosti. Njegov esej Svobodni duh je 
prvi pomembnejši izraz samozavedanja teh mladih piscev, v njem izražene ideje pa je kasnejša literarna veda pogosto nekritično povzemala. Mogoče je prav pod njegovim vplivom poudarila pomen preloma $\mathrm{z}$ itografijo za izoblikovanje generacije tridesetih. Sledeč Teotokasu slednji očita nepsihološkost, čeprav je itografija grški književnosti dala med drugim naturalističnega klasika, kakršen je Papadiamantis, avtor psihološko prepričljive povesti o ženski usodi Morilka. Teotokas je v času obstoja generacije tridesetih, ki jo je sam pokopal že leta 1940, izdal dva romana, v katerih je poskušal udejanjiti svoje teoretične poslanice.

\section{LITERATURA}

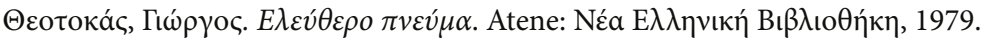

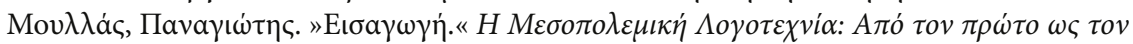

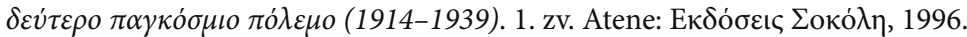

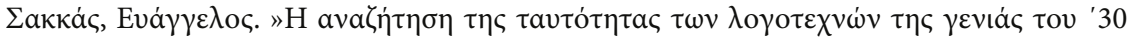

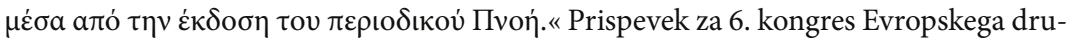
štva novogrških študijev (The 6th Congress of the European Society of Modern Greek Studies), http://www.eens.org/ (obiskano 28. 7. 2018).

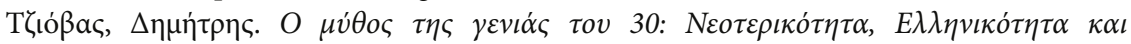

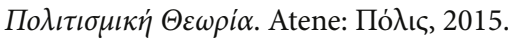

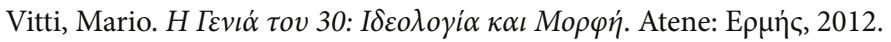

\section{PRILOGA}

\section{Jorgos Teotokas: Demon}

Odlomek iz romana

Nenadoma je neki drug zvok, grob in hrapav, pretrgal čar. Romilos se je meni nič, tebi nič začel smejati s počasnim, glasnim in odvratnim smehom, zlonamernim in sarkastičnim. Ifigenija je nehala recitirati in mu je pogledala naravnost v oči. Tudi on se je nehal bedasto režati in se je zresnil.

Pesniške vizije so se v enem samem hipu do kraja razblinile; vzdušje v izbi je postalo ledeno. Pogleda brata in sestre sta se prekrižala, sijoča kakor razgaljena meča. V njunem spopadu sem zaslutil nekakšno nagonsko neomajnost, enako intenzivnost duševnega življenja pri obeh, ki pa jima ni dopuščala, da bi drug drugega prenašala - zares, intenzivnost, ki je v meni za hip vzbudila vtis, da je na griču Hristofidisov zavel veter norosti. Potem je Ifigenija, ne da bi še kaj rekla in ne da bi se še enkrat obrnila k nam, zapustila izbo. Videl sem, kako je stari učitelj za trenutek vzdrhtel po celem telesu. Toda ni spregovoril ne on ne nihče drug. Zdi se, da so bili v tej družini takšnih prizorov vajeni in jih niso presenečali. 
Končno sem vstal, da bi odšel. Privzdignil pa se je tudi Romilos, kot bi mi hotel zastaviti pot. Mogoče si je moj odhod razlagal s tem, da ne odobravam njegovega obnašanja.

»Zakaj odhajaš? «me je preteče vprašal.

Zelo dobro sem poznal izraz, ki se mu je pojavil na obrazu. Nemudoma sem ga poskusil obrzdati s tonom glasu. Pogledal sem mu naravnost v oči, tudi sam preteče.

»Moram iti, « sem mu suho odvrnil. »Čakajo me.»

»Zakaj odhajaš? « je trmasto ponovil vprašanje.

Vseeno se je umaknil in me spustil mimo. Vsi ostali so bili kakor okamneli od nenadnega pihljaja norosti. Mati in fant sta me opazovala vsa otrpla, brezizrazna in tiha. Starec ni več drhtel, spominjal je na umrlega. Tu notri je bilo žalostno, mogoče tudi malo divje. Poslovil sem se in odšel, ne da bi komur koli podal roko in ne da bi mi kdor koli odzdravil.

Bil je že pozen večer; na nebesnem svodu ni bilo več niti odbleska sončnega zahoda. Luna se je dvignila visoko, na tri četrt polna. $\mathrm{V}$ sivem večernem mraku je poleg nje zasijala ena sama zvezda. Prižgalo se je tudi nekaj luči v pristanišču. S hitrimi koraki sem se spustil proti obalni cesti, globoko sem vdihaval morski zrak. Potreboval sem čist zrak.

Na obali Petresa je stala skala, nekam glajša od ostalih, ki se je spuščala v morje kakor rtič in ustvarjala nekakšno teraso. Od daleč sem uzrl, da na tej skali sedi človeška senca, in mislil sem si, da bo to najbrž moj prijatelj Jean Malcolm, kanadski arheolog. Vedel sem, da se včasih, kadar sije luna, rad povzpne tja gor in se prepusti mislim. Nameril sem se torej tja, da bi se usedel poleg njega in mu povedal o svojih vtisih s tega čudaškega večera. Ko pa sem stopal predse, sem zagledal drugo senco, ki se je v teku spuščala po pobočju griča Hristofidisov. Ustavil sem se, da bi videl, kdo je, in kmalu sem prepoznal Romilosa.

Bil je besen. Takoj sem zaslutil, kaj se bo zgodilo. Postavil se je predme in se oglasil nesramno, z zasoplim glasom.

»Rad bi vedel, «je rekel, »zakaj si tako nenadoma odšel, ne da bi mi podal dlan.«

»Pravico imam, " sem mu odgovoril, »da odidem, kadar hočem, in da ti ne podam dlani, kadar mi ni do tega, da bi ti jo podal.«

»Ne,« je zavpil, »nimaš me pravice takole žaliti v moji lastni hiši.«

»Romilos, « sem mu rekel, kolikor strogo sem znal, »ti si mogoče nor, jaz pa nisem, in nisem razpoložen za nore prepire. Pojdi stran in me pusti pri miru! «

Takrat je do kraja pobesnel, dvignil je roko in me z odprto dlanjo močno klofnil po obrazu. Najprej sem zaslišal plosk klofute, ki je težko odmeval v večerni tišini. Potem sem začutil, kako sem se stresel od udarca. Kri mi je udarila v glavo, srce mi je divje razbijalo. Nič več nisem mislil. V trenutku, mehanično, sem ga $\mathrm{z}$ vso močjo, kar sem je premogel, s pestjo udaril v brado. 
Ko se ga je moja roka dotaknila, sem začutil, kako se me polašča nenavadno telesno ugodje. Vsi moji instinkti so se razgalili in se razdivjali.

Romilos se je ves zamajal od udarca in naredil nekaj korakov nazaj. Toda z umikom je pridobil zalet; planil je naprej, tudi on z vso močjo, in me začel $s$ pestmi obeh rok obkladati po glavi in prsih. Sam sem počel isto. Moji živci in nagoni so bili tako napeti, da sploh nisem več občutil bolečine. Slišal sem samo tleskajoče udarce, enega za drugim. V nekaj trenutkih sva se čvrsto objeta v klopčiču kotrljala po tleh. Videl sem luno, kako poskakuje po nebu, in Jeana Malcoma nekaj korakov stran, kako molče opazuje boj.

Tako sva se nekaj časa valjala. Najine roke so bile izčrpane, nisva več mogla udarjati. Zdaj sem poslušal paranje najinih oblačil. V ustih sem imel zemljo. Čutil sem, kako mi obalni kamni prebadajo hrbet. Telo mojega nasprotnika, prav tako robato kakor kamni, je bilo po vsej dolžini iztegnjeno na meni v objemu sovraštva. Na koncu nama je do kraja zmanjkalo moči in sva obmirovala. Nič drugega ni bilo več mogoče.

Takrat se nama je Kanadčan približal in vzkliknil: »Remi!«

Precej dobro je govoril grško.

»Dovolj!« je ponovil in me narahlo potrepljal po rami. »Get up!«

Zrahljal sem stisk in začutil, da ga je bil tudi Romilos pripravljen zrahljati. Oba sva bila zdelana. Počasi sva se razpletla in se trudoma dvignila. Moj suknjič je bil na več mestih strgan in je ostal brez gumbov.

»Kri imaš na obrazu, « mi je rekel Kanadčan.

Dal mi je čist robec. Šel sem k morju, ga namočil in si umil obraz. Vse telo me je bolelo.

Ko sem se vrnil na kraj, kjer sva se stepla, sem tam našel samo Malcolma, ki si je prižgal cigareto.

»e odšel?« sem ga vprašal.

» $\mathrm{Ja}$, " mi je odgovoril. »Rekel je, da ne ve, kaj se je zgodilo.«

»Nor je, « sem rekel.

»Ne, « mi je resno odvrnil Malcolm. »Ni nor. Malo je dreamy. Kako vi temu rečete? Sanjač ...»

$» \mathrm{~K}$ vragu s takšnimi sanjami!« sem rekel. »Pojdiva se usest. Malo sem utrujen."

Nisem bil dovolj pri močeh, da bi splezal na skalo s teraso, zato sva se usedla na tla na obali. Še sam sem si prižgal cigareto.

»Prvič sem stopil v to hišo, « sem povzel besedo, "ampak nikoli več ne grem tja. Vsi skupaj so nori.«

Tedaj sem se spomnil Ifigenijinega glasu in začutil, kako v meni narašča zamera. Toda zdaj je bila pomešana s sladkim občutkom ljubečega občudovanja. In bolj ko se je v meni razraščala sladkost spomina nanjo, bolj se je razvnemal srd, ki me je napolnjeval. Zdaj sem jo čisto zares sovražil, ker je živela med temi čudnimi ljudmi in je bila čudna in nerazumljiva kakor oni, ker se je do mene vedla s takšno zaničljivo brezbrižnostjo, ker je bila razlog, 
da sem se pretepal po cestah kot kakšna baraba. Predvsem pa sem jo sovražil, ker me je očarala.

»Dekle, « sem jezno rekel, »je po vsem videzu obsedeno s Shakespearjem, z gledališčem - kaj vem s čim! Vsi tam so obsedeni s čim norim. Ona je recitirala, Romilos pa se je smejal in jo poniževal. Povabijo te $\mathrm{k}$ sebi domov in te potem lovijo po cesti, da bi te pretepli. Niso mi všeč ti ljudje.«

»Ja, zelo rada ima Shakespearja, " je zamišljeno rekel Malcolm. »Veliko stvari razume. Če bi študirala v Angliji, bi lahko igrala v Shakespearju in postala velika osebnost.«

»Oni vsi mislijo, da so velike osebnosti, « sem mu odgovoril v enakem tonu kot prej. "Zato pa jih nihče na otoku ne mara. Z nadutostjo in svojimi čudaštvi so se vsem zamerili in nihče več ne zahaja k njim.«

»Mogoče imajo kaj velikega v sebi, ampak še sami ne vedo, kaj in kaj bi s tem, « je rekel Malcolm.

Moj tuji prijatelj je običajno govoril na takšen način, da nisi mogel biti prepričan, ali govori resno ali se šali. Kar koli je pripovedoval, vedno je govoril $\mathrm{z}$ istim mirnim in zamišljenim tonom, pa naj se je ravno zabaval ali se prepiral, najsi je pripovedoval šale in obrekoval ali pa se pogovarjal o resnejših temah, ki so ga zanimale. Ni se zlahka smejal in redko se je nasmehnil. Toda oči so se mu včasih nasmejano in nagajivo pobliskavale, in sicer brez vsake hudobije, in so vzbujale sum, da se norčuje. Toda med tem najinim pogovorom o Hristofidisovih nisem videl njegovih oči in ne vem, kaj točno je hotel reči.

»To so pravljice, « sem mu glasno odgovoril. »Na tem otoku se dobro poznamo med seboj. Tukaj ni genijev. Tu je samo nekaj nepomembnih in nerazumnih provincialcev, ki sanjarijo o velikem življenju in izjemnih delih, in ker ne najdejo načina, da bi dosegli eno ali drugo, se jih polaščajo melanholije in živčne bolezni. To je vsa skrivnost Hristofidisovih in raznih drugih družin, ki jih poznam.«

Jean Malcolm mi je tiho ugovarjal:

»Stari mož je genius, « je rekel, »toda tega ne bo nikoli nihče izvedel. Genius je izključno sam zase. In tudi v Ifigeniji je bil včeraj genius. Zaigrala je Rosalind iz As you like it. Oblekla se je v obleko svojega mlajšega brata. Nekatere verze je zdeklamirala $v$ grščini in nekatere v angleščini. Nikoli ne bom pozabil tega prizora."

Tedaj sem se spomnil, da sem slišal, da je Jean Malcom učil Ifigenijo angleščine. Spomnil sem se tudi čenče, ki je krožila po otoku pred enim letom, češ da je bil zaljubljen v Ifigenijo in jo je zasnubil, toda ona ni marala ne njega ne nikogar drugega. $Z$ vsem tem se nisem prej nikoli ukvarjal, ker me, vse do tistega večera, ni Ifigenija niti najmanj zanimala in me ni brigalo, kdo je zaljubljen vanjo in kdo jo poučuje.

Po dogodkih tega večera pa so vse te zadeve naenkrat zadobile drugačen pomen. Bolje sem razumel svojega prijatelja. Bolje sem ga poznal. Počutil sem se mu veliko bližji in bolj povezan z njim. Nenadoma naju je, ne da bi on to 
slutil, združila globoka, skrivna in topla solidarnost, ki naju je ločevala od vseh ostalih - hkrati pa je bila meglena in zaskrbljujoča, saj se je vanjo mešala slutnja sovraštva. Lahko bi rekli, da je vse viselo na nitki, in kaj čisto nepomembnega bi bilo dovolj, da bi se vse utopilo v mržnji.

Zasukal sem se in ga pogledal v prozornem mraku. Bil je mladenič, star največ kakšnih štiriindvajset let, visok, svetlolas, močen, nežnih in plemenitih potez. V pogledu in obnašanju je imel nekaj zelo nedolžnega, nekakšno brezskrbno in nepokvarjeno otroškost, ki jo je, kot se je zdelo, nameraval obdržati za vedno. Ime mu je bilo John, toda ime je zapisoval Jean po francoski ortografiji in ga izgovarjal po angleško Džin. Študiral je na Oxfordu in je bil štipendist Britanske arheološke šole $\mathrm{v}$ Atenah. Prihajal je na naš otok in ga zapuščal vse od prejšnjega poletja, opravil je nekaj manjših izkopavanj na nekem kraju, ki se mu reče Fitema, ne verjamem pa, da je kdaj našel kaj omembe vrednega. Toda vzljubil je okolico, neprestano je popotoval od vasi do vasi in se je imenitno sporazumeval $\mathrm{z}$ našimi vaščani. Ni zamudil nobene veselice. In ker je na našem otoku kakšnih štirideset vasi in ima vsaka svojo lastno veselico, nekatere pa celo po dve ali tri na leto, je bil Jean s tem precej zaposlen. Napotil se je proti vasi, ki je praznovala, čisto sam ali s prvo naključno družbo, ki jo je srečal, in se zabaval vso noč, plesal je grške plese na trgu in zelo ognjevito pil. Bil je zelo ljudski človek; povsod so ga gostili, kot bi bil kakšen njihov otrok, ki se vrača iz tujine. Pravili so mu »Džinis«. In slišal si vzklike in trušč: »Prišel je Džinis! Dobrodošel, Džinis! Živijo, Džinis!« Vaški otroci so tekali za njegovo mulo, gospodinje so mu na pladnju prinašale uzo skupaj z olupljenimi mandlji in praženo čičeriko, starešine so mu pripravljali izbo.

Spoprijateljila sva se prejšnje poletje in sva bila drug drugemu prijetna družba v pristaniških tavernah in na različnih vaških veselicah. Hodila sva tudi na dolge morske izlete in po cele noči ribarila z ribiškimi barkami. Jeanu se je vse zdelo imenitno in čudovito, ničemur ni ugovarjal. Pozimi sva se pogosto srečevala v Atenah, skupaj sva obredla kinematografe, bil sem tudi pri njem na večerji v Britanski šoli, sam pa sem ga povabil na dobrodelni ples, $v$ hotel na ulici Patision, in zazdelo se mu je primerno, da se na njem prikaže oblečen v fustanelo, moško krilo. Predstavljal si je, da bo Grkom pokazal svojo naklonjenost, če si bo, tujec, nadel njihovo narodno nošo. Grki pa so bili vsi oblečeni v črno, leseni in zastrašujoči, saj je bil to resen, še več, svečan ples, in ko so videli moškega v fustaneli, kako tava med njimi, so se zelo začudili. Eden izmed organizatorjev se je Jeanu nadvse vljudno približal in ga vprašal: »Ste Grk, gospod? « Ne, « mu je odgovoril Jean, »Anglež sem. «In vsem se je zdelo zelo naravno in običajno, da se Anglež obleče v fustanelo, govorili so celo, da si lahko samo Anglež nadene takšno oblačilo sredi Aten.

Zdaj sem ga pogledal pozorno in vznemirjeno. Bil je lep, res, in tako drugačen od vseh nas! V sebi je imel vso mladostnost in spontano gosposkost anglosaškega naroda. Imel je tudi nekaj nedolžne in oživljajoče svežine velikih belih planjav svoje severne domovine. Lahko bi bil všeč kakšnemu dekletu, 
lahko bi mu bil zelo všeč. Govorice so sicer pravile, da ga je ta vsa v svojih fantazijah izgubljena Ifigenija zavrnila, ko jo je zasnubil. Toda ona, kot vse kaže, sama ne ve, kaj blekne, tako je vsa obsedena s svojimi čudaštvi in sanjarijami. Mogoče si bo jutri zjutraj že premislila. Poleg tega je imela rada Shakeaspearja. Jean pa je bil neke vrste Anglež, in kadar so mu zastavljali nadležna vprašanja, je odgovarjal: »Anglež sem!« Celo angleščine jo je učil. Lahko bi ju Shakespeare in angleščina na koncu združila.

Naenkrat sem za trenutek občutil silovito antipatijo do Jeana Malcolma, do Shakespearja, do njunega jezika in do vseh Rozalind in Hermij in drugih shakespearskih prikazni, ki so se podile po griču Hristofidisov. Kaj so vsi ti tujci iskali na našem otoku? Kaj so hoteli od naših deklet? S kakšno pravico so vdirali preko meja naše otoške samote in burkali navade našega življenja, naša premišljevanja in fantazije.

»Poberejo naj se! Poberejo!« sem zavpil v sebi. Napolnjevala me je jeza, pa še sam nisem prav dobro vedel, zakaj. Ljubosumje je v moji zavesti privzelo obliko domoljubnega odpora proti nekakšnemu vdoru tujcev. Moje ljubosumje je spregovorilo v imenu tradicije in narodne neodvisnosti.

Noč se je do konca spustila na naš otok, srebrna, eksotična noč. Luna je bila na višku svoje slave; pogasila je zvezde vsenaokrog in ves svet je bil zdaj njen. Bleščeča reka bele svetlobe je parala morje po vsej dolžini. V daljavi so se razblinjali drugi otoki, popotovali so po vodni površini kakor tančice megle ...

»Naj se poberejo? « sem premišljeval. »Kdo naj se pobere in zakaj? Od kod to nesmiselno sovraštvo, ta nenadni izbruh hudobije sredi tolike lepote in tolikega miru? « Spet sem pred seboj uzrl podobo Ifigenije, kakršno sem toliko let videval na cestah naše skupnosti, hitro, osorno, zatopljeno v neznane misli, s pogledom, zapičenim v prazno, z izrazom, ki odvrača.

»Sem mar zaljubljen, « sem se vprašal, »v to zoprno dekle?»

\section{IZVLEČEK}

\section{Svobodni duh Jorgosa Teotokasa in koncept generacije tridesetih}

V prispevku poskušam prikazati, na kakšen način so si pripadniki generacije tridesetih, grškega literarnega gibanja v obdobju med obema vojnama, ustvarjali skupno identiteto ali se ji odrekali in kako so se samodefinirali kot "generacija", ne da bi se pri tem kadar koli povezali $\mathrm{v}$ formalno književno šolo. Ugotavljam tudi, kako so s tem vplivali na trditve kasnejše literarne zgodovine. Članek vsebuje kratko predstavitev situacije v grški književnosti pred nastopom generacije tridesetih, saj je pojem preloma s tradicijo oziroma reinterpretacije književne zapuščine osrednji člen njihove samoopredelitve. Osredotočam se na Jorgosa Teotokasa in na njegov prispevek k oblikovanju njihovega »mita«, kakor ga poimenuje sam, ter predstavljam njegov prvi in poglavitni esej Svobodni duh. 


\section{ABSTRACT \\ The Free Spirit by Yorgos Theotokas and the Concept of the Generation of the ' 30 s}

This paper presents the way in which the members of the Generation of the '30s, a Greek literary movement in the interwar period, formed their collective identity or denied it, and how they defined themselves as a 'generation' without ever creating a formal literary school. I also observe how this affected the conclusions of later literary historians. The article contains a brief presentation of the situation in Greek literature before the appearance of the Generation of the '30s, since the notion of a break with tradition or else reinterpretation of literary heritage was at the core of their self-definition. I focus mainly on the work of Yorgos Theotokas and his contribution to the forming of their 'myth', as he calls it himself, and present his first and most important essay, The Free Spirit. 